\title{
Validitas E -Modul Berbasis Open Ended Meteri Sistem Persamaan Linear Dua Variabel Pada Pembelajaran Daring untuk Siswa SMK
}

\author{
Salma Aprianka ${ }^{1}$, Ana Setiani ${ }^{2}$, Aritsya Imswatama ${ }^{3}$ \\ 1,2,3 Program Studi Pendidikan Matematika, Fakultas Keguruan dan Ilmu Pendidikan, Universitas Muhammadiyah Sukabumi, \\ Jl. R. Syamsudin, S.H. No. 50, Kota Sukabumi \\ apriankasalma@gmail.com
}

\begin{abstract}
This study aims to determine the validity of e -module developed. This research uses Research and Development $(\mathrm{R} \& \mathrm{D})$ research method. The design used in this research is ADDIE design which has 5 stages of development model namely Analysis, Design, Development, Implementation, and Evaluation. However, because the author has all the limitations, the author divides the stages of this development research into three stages, namely Analysis, Design, and Development. To find out the quality of e-module developed then the researchers conducted a questionnaire analysis with a likert scale. Validation is performed by three validators from material experts and media experts. The conclusion obtained from this study is validation value results from media experts get a value of $90 \%$ with a very decent category. Media validation assessment focuses on the assessment of aspects of module size, and the design of e-modules. Then the results of validation values from material experts get a value of $84 \%$ with a very decent category. The material validation assessment focuses on assessing aspects of content feasibility, presentation feasibility, language feasibility, and contextual assessment. Thus E-Module based on open ended Material System Linear Equation Two Variables on online learning for vocational students is valid and very feasible to be used as a math teaching material because it meets the assessment criteria.
\end{abstract}

Keywords: E - Module, Open Ended, Research and Development, Validity, In-Network

\begin{abstract}
Abstrak
Penelitian ini bertujuan untuk mengetahui validitas dari e-modul yang dikembangkan. Penelitian ini menggunakan metode penelitian Research and Development (R \& D). Desain yang digunakan dalam penelitian ini adalah desain ADDIE yang memiliki 5 tahap model pengembangan yaitu Analysis, Design, Development, Implementation, dan Evaluation. Namun dikarenakan penulis memiliki segala keterbatasan maka penulis membatsi tahapan penelitian pengembangan ini menjadi tiga tahapan yaitu Analysis, Design, dan Development. Untuk mengetahui kualitas dari e-modul yang dikembangkan maka peneliti melakukan analisis angket dengan skala likert. Validasi dilakukan oleh tiga validator dari ahli materi dan ahli media. Kesimpulan yang diperoleh dari penelitian ini yaitu hasil nilai validasi dari ahli media mendapatkan nilai sebesar $90 \%$ dengan kategori sangat layak. Penilaian validasi media berfokus pada penilaian aspek ukuran modul, dan disain e-modul. Kemudian hasil nilai validasi dari ahli materi mendapatkan nilai sebesar $84 \%$ dengan kategori sangat layak. Pada penilaian validasi materi berfokus pada penilaian aspek kelayakan isi, kelayakan penyajian, kelayakan kebahasaan, dan penilaian kontekstual. Maka EModul berbasis open ended Materi Sistem Persamaan Linear Dua Variabel pada pembelajaran daring untuk siswa SMK ini valid dan sangat layak untuk digunakan sebagai bahan ajar matematika karena memenuhi kriteria penilaian.
\end{abstract}

Kata Kunci: E-Modul, Open Ended, Penelitian dan Pengembangan, Validitas, Dalam Jaringan (Daring)

Copyright (c) 2021 Salma Aprianka, Ana Setiani, Aritsya Imswatama

$\square$ Corresponding author: Salma Aprianka

Email Address: apriankasalma@gmail.com (J1. R. Syamsudin, S.H. No. 50, Kota Sukabumi)

Received 17 July 2021, Accepted 04 October 2021, Published 12 October 2021

\section{PENDAHULUAN}

Dunia saat ini sedang dihadapkan dengan wabah virus covid-19 atau yang sering disebut dengan corona. Penyakit ini muncul pertama kali di Wuhan China lalu menyebar hampir di seluruh penjuru dunia tidak terkecuali Indonesia. Munculnya covid 19 di Indonesia ini berdampak bagi seluruh lapisan masyarakat. Dampak yang ditimbulkan dari covid 19 ini mempengaruhi beberapa bidang seperti, bidang pariwisata, bidang perekonomian, bidang sosial dan bidang pendidikan. Semakin meningkatnya kasus 
positif covid19 ini menyebabkan pemerintah mengambil tindakan untuk penutupan di beberapa sektor salah satunya penutupan sektor pendidikan. Penutupan ini bertujuan untuk menurunkan grafik kasus posotif covid19. Dampak dari penutupan bidang pendidikan seperti sekolah, ini membuat proses belajar mengajar di sekolah terhambat.

Menteri Pendidikan dan Kebudayaan Republik Indonesia mengeluarkan Surat Edaran Nomor 4 Tahun 2020 Tentang Pelaksanaan Kebijakan Pendidikan Dalam Masa Darurat Penyebaran COVID, dalam surat edaran tersebut dijelaskan bahwa pembelajaran tatap muka di sekolah di gantikan dengan Pembelajaran Jarak Jauh (PJJ) atau pembelajaran dalam jaringan (daring) dari rumah dengan bimbingan orang tua. Pembelajaran daring merupakan pembelajaran yang dilakukan dengan bantuan alat elektronik seperti komputer, laptop ataupun handphone yang membutuhkan kuota atau data seluler. Pembelajaran daring ini memungkinkan proses belajar mengajar tanpa harus tatap muka secara langsung di kelas.

Pada pembelajaran daring baik siswa maupun guru dituntut dapat memaksimalkan penggunakan teknologi pada saat pembelajaran. Sejalan dengan tuntutan pembelajaran abad 21 maupun kurikulum 2013, yaitu mengintregasikan teknologi dalam dunia pendidikan. Integrasi teknologi yang selama ini dilakukan hanya seputar menerapkan penggunaan teknologi sebagai media pembelajaran pendukung dalam proses pembelajaran, dan belum menjadikannya satu tubuh yang utuh dengan proses pembelajaran (Ramadhani \& Fitri, 2020). Permendikbud No. 65 Tahun 2013 yang menyatakan bahwa Kurikulum 2013 memfokuskan pada penggunaan integrasi teknologi dan komputer dan proses pembelajaran (MENDIKBUD, 2013).

Guru di tuntut lebih kreatif dalam pemanfaatan teknologi. Seperti pembuatan bahan ajar berbasis elektronik yang bertujuan untuk mempermudah proses pembelajaran. Serta siswa dapat menggunakannya tidak hanya saat pembelajaran berlangsung tapi juga dapat di akses kapan saja dan dimana saja. Penerapan teknologi dalam proses pembelajaran memberikan dampak terhadap peningkatan kualitas pembelajaran dan menjadikan proses pembelajaran menjadi lebih efektif, praktis serta dapat meningkatkan pengetahuan hingga keterampilan tambahan bagi guru maupun siswa (Ramadhani et al., 2019).

Namun yang saat ini terjadi di lapangan pemanfaatan teknologi belum maksimal. Masih banyak guru yang menggunakan metode pembelajaran konvensional dan menggunakan bahan ajar yang belum berbasis teknologi Berdasarkan hasil wawancara dengan guru di SMK. Guru masih menggunakan bahan ajar berupa buku paket, serta pada saat pembelajaran daring guru hanya memberikan video pembelajaran tentang pemaparan materi secara singkat. Sehingga siswa tidak memiliki buku ataupun modul untuk memperdalam materi pembelajaran. Pembelajaran dengan model tersebut belum mampu mendorong siswa untuk belajar secara mandiri karena pembelajaran lebih banyak bertumpu pada guru. Selain itu akibat pembelajaran yang dilakukan secara daring tidak adanya interaksi antara siswa dan guru. Sehingga pembelajaran hanya bertumpu kepada guru.

Hal inilah yang dapat mengakibatkan tidak efektif nya pembelajran. Sehingga tingkat keberhasilan pembelajaran sangat kecil. Hasil pembelajaran yang masih rendah dapat dipengaruhi oleh 
beberpa faktor diantaranya faktor model pembelajaran yang digunakan masih terpusat pada guru serta bahan ajar yang belum memadai untuk meningkatkan hasil belajar siswa. Hal tersebut selaras dengan hasil wawancara kepada guru matematika di SMK yang masih menggunakan bahan ajar berupa buku paket yang berisikan materi dan latihan soal yang monoton. Sehingga tidak membantu siswa untuk memahami materi pembelajaran. Berdasarkan hasil wawancara kepada guru matematika di SMK Hassina, beliau mengatakan belum pernah mengembangkan bahan ajar. Selain itu, hasil dari pengisian kuesioner siswa menginginkan diadakannya bahan ajar untuk membantu proses pembelajaran siswa agar siswa dapat lebih mengeksplore pengetahuannya dengan latihan soal. Bahan ajar yang diharapkan siswa tidak hanya berisikan materi dan latihan yang monoton. Tetapi berisikan animasi yang menarik agar pembelajaran terasa tidak membosankan. Bahan ajar merupakan segala bahan baik informasi, alat, maupun teks yang disususn secara sistematis, yang menampilkan sosok yang utuh dari kompetensi yang akan dikuasi peserta didik dan digunakan dalam proses pembelajaran dengan tujuan perencanaan dan penelaahan impelementasi pembelajaran (Rahmadani et al., 2018). Salah satu jenis bahan ajar yaitu Emodul.

E-modul merupakan bentuk modul secara digitalize dan dikemas dengan lebih interaktif. Emodul disebut juga media untuk belajar mandiri karena di dalamnya telah dilengkapi petunjuk untuk belajar sendiri. Selain itu menurut (Wijayanto \& Zuhri, 2014) E-modul merupakan alat atau sarana pembelajaran yang berisi materi, metode, batasan-batasan dan cara mengevaluasi yang darancang secara sistematis dan menarik untuk mencapai kompetensi yang di harapkan sesuai dengan tingkat kompleksitasnya secara elektronik. E-modul dapat diisi materi dalam bentuk pdf, video serta animasi yang mampu membuat pengguna belajar secara aktif. Adapun software yang digunakan untuk pembuatan e-modul adalah Flip PDF Pro dengan hasil akhir e-modul berupa flipbook. Flip PDF Pro adalah perangkat lunak yang efisien dan kuat yang dirancang untuk membantu pengguna membuat buku gambar, buku 3D, majalah dan brosur digital. Dengan perangkat lunak ini dapat mengonversi file PDF ke halaman jurnal digital.

Selain penggunaan e-modul yang tepat penggunaan model pembelajaran yang tepat juga penting. Penggunaan model pembelajaran yang tepat juga dapat meningkatklan hasil pembelajaran siswa.Siswa cenderung menghafal rumus, meniru contoh soal yang diberikan oleh pendidik, dan kurangnya peserta didik saat memahami materi.Sehingga tiap kali diberikan soal matematika yang berbeda, peserta didik belum mampu mengerjakan soal, sehingga dapat dsimpulkan kemampuan peserta didik tergolong memiliki kemampuan rendah dalam menyelesaikan soal meskipun telah diberi buku pegangan (Nugroho et al., 2017).

Oleh karena itu perlu mengembangan e-modul dengan model pembelajaran yang dapat meningkatkan kemampuan berfikir kritis, mengemukakan ide - idenya baik secara lisan maupun tulisan dan meningkatkan kreatifitas matematika siswa. Solusi yang dapat dipilih untuk mengatasi masalah yang terjadi adalah proses pembelajaran menggunakan pendekatan open ended. Pentingnya open ended di kemukakan oleh Sudiarta, P., \& Putu (2005) dengan siswa memiliki open ended siswa dapat 
meningkatkan pemahaman siswa terhadap konsep-konsep matematika yang akhirnya akan meningkatkan hasil belajar siswa. Pendekatan tersebut juga dapat membuat siswa aktif dan kreatif, karena siswa tidak hanya menemukan solusi tetapi juga memberikan argumen dari jawabannya sendiri. Penerapan pendekatan open ended dalam kegiatan pembelajaran yang sudah terangkum dalam media pembelajaran ini diharapkan dapat meningkatkan pemahaman penguasaan peserta didik terhadap materi yang di pelajari terutama materi system persamaan linear dua variabel.

Berdasarkan penjabaran permasalahan di atas, peneliti berupaya mengembangkan bahan ajar matamatika berupa e-modul dengan pendekatan open ended yang berbeda dari e-modul pada umum nya karena e-modul yang dibuat akan berbentuk flipbook dan terdapat video penjelasan yang dapat diakses peserta didik langsung di dalam e-modul dengan fitur video yang layarnya dapat diperbesar layaknya menonton video di kana youtube.Serta e-modul ini dapat di akses di laptop atau PC secara gratis tanpa memerlukan data internet.Tidak hanya itu e-modul ini juga dapat di akses semua jenis handphone dengan menggunakan data internet. Dengan demikian penelitian pengembangan yang dilaksanakan ini berjudul Validitas E-Modul berbasis open ended Materi Sistem Persamaan Linear Dua Variabel pada pembelajaran daring untuk siswa SMK.

\section{METODE}

Penelitian pengembangan e-modul berbasis open ended ini menggunakan metode penelitian Research and Development ( $\mathrm{R} \& \mathrm{D}) . \mathrm{R} \& \mathrm{D}$ adalah suatu proses atau langkah-langkah untuk mengembangkan suatu produk baru atau menyempurnakan yang telah ada yang dapat dipertanggungjawabkan (Muqdamien et al., 2021). Sugiyono (dalam Haryati, 2012) berpendapat bahwa, metode penelitian dan pengembangan adalah metode penelitian yang digunakan untuk menghasilkan produk tertentu, dan menguji keektifan produk tersebut. Desain yang digunakan dalam penelitian ini adalah desain ADDIE yang memiliki 5 tahap model pengembangan yaitu Analysis, Design, Development, Implementation, dan Evaluation. Namun dikarenakan penulis memiliki segala keterbatasan maka penulis membatsi tahapan penelitian pengembangan ini menjadi tiga tahapan yaitu Analysis pada tahap ini dilakukan identifikasi apa yang akan dibuat untuk menunjang pembelajaran peserta didik agar dapat mengatasi permasalahan yang ada dalam proses pembelajaran matematika di sekolah. Maka dari itu untuk mengetahui atau menentukan apa yang harus dibuat, harus melakukan beberapa kegiatan, diantaranya adalah melakukan needs assessment (analisis kebutuhan)., Design pada tahap ini dikumpulkan informasi terkait e- modul yang akan di kembangkan sesuai kebutuhan dan permasalahan yang sudah di analisis di tahap awal. Desain yang akan dikembangkan pada produk ini yaitu e - modul berbasis open ended untuk meningkatkan kemampuan berpikir kreatif matematis siswa., dan Development pada tahap ini mulai melakukan pengembangan produk dan instrumen yang akan digunakan. Pada tahap ini terdiri dari dua bagian yaitu tahap pengembangan produk, dan tahap penilaian produk menggunakan intrumen yang telah dirancang Emodul ini disusun berdasarkan rancangan yang telah dibuat serta berdasarkan saran dari dosen pembimbing. E-modul berbasis open ended yang 
dikembangan lalu masuk ketahap penilaian validasi. Validitas ini terdiri dari validitas media, validitas materi, serta validitas tes kemampuan berpikir kreatif matematis. Validitas ini dilakukan oleh validator ahli yang masingmasing berjumlah tiga orang.

Untuk mengetahui kualitas dari e-modul yang dikembangkan maka peneliti melakukan analisis angket dengan skala likert. skala likert.Menurut Riduwan (Sundayana, 2010), bahwa Skala Likert digunakan untuk mengukur sikap, pendapat, dan persepsi seseorang atau sekelompok tentang kejadian atau gejala sosial. Skala yang digunakan untuk menghitung hasil angket yang disebar yaitu skala Likert dengan 5 pilihan yaitu sangat baik (SB), baik (B), cukup baik (CB), kurang baik (KB) dan sangat kurang baik (SKB). Adapun analisis data yang digunakan yaitu analisis deskriptif dengan langkah - langkah sebagai berikut.

1. Menghitung rata - rata jumlah skor yang diperoleh menggunakan rumus berikut

$$
\bar{X}=\frac{\sum x}{n}
$$

Keterangan:

$\bar{X}=$ Rata - rata

$\sum x=$ jumlah skor yang diperoleh

$n=$ jumlah validato

2. Menghitung persentase hasil penilaian dengan menggunakan rumus berikut.

$$
\text { Hasil }=\frac{\text { Total skor yang diperoleh }}{\text { skor maksimum }} \times 100 \%
$$

3. Memberikan kriteria berdasarkan skor likert yang di modifikasi sebagai berikut

Tabel 1 Kriteria Kelayakan E - modul

\begin{tabular}{|c|c|}
\hline Skor dalam persen (\%) & Kriteria \\
\hline $81 \%-100 \%$ & Sangat layak \\
\hline $61 \%-80 \%$ & Layak \\
\hline $41 \%-60 \%$ & Kurang Layak \\
\hline $21 \%-40 \%$ & Tidak Layak \\
\hline$<21 \%$ & Sangat Tidak Layak \\
\hline
\end{tabular}

(Sumber :Suharsimi Arikunto \& Jabar, n.d.)

\section{HASIL DAN DISKUSI}

Pengembangan e - modul berbasis open ended ini melalui tiga tahap yaitu tahap Analysis, Design, dan Development. Adapun hasil tahapan tersebut yaitu.

\section{Tahap Analisis (Analysis)}

Dalam tahapan ini, kegiatan utama adalah menganalisis perlunya pengembangan bahan ajar dalam tujuan pembelajaran (Cahyadi, 2019). Suatu proses mendefinisikan apa yang akan dipelajari oleh peserta didik. Maka untuk mengetahui atau menentukan apa yang harus dipelajari, kita harus melakukan beberapa kegiatan, diantaranya adalah melakukan needs assessment (analisis kebutuhan), mengidentifikasi masalah (kebutuhan), dan melakukan analisis tugas (task analysis). Pada tahap ini dilakukan survei dengan menyebarkan angket mengenai kebutuhan e-modul kepada peserta didik untuk 
menentukan produk yang akan dikembangkan dan mengidentifikasi nilai ulangan matematika pada materi sistem persamaan linier dua variabel. Kemudian dilakukan identifikasi masalah yang ada di sekolah dan hasil dari identifikasi masalah tersebut yaitu proses pembelajaran matematika di sekolah masih menggunakan bahan ajar berupa buku paket yang berisikan materi dan latihan soal yang monoton. Sehingga tidak membantu siswa untuk memahami materi pembelajaran. Berdasarkan hasil wawancara kepada guru matematika di SMK Hassina, beliau mengatakan belum pernah mengembangkan bahan ajar berupa e - modul. Selain itu, hasil dari pengisian kuesioner siswa menginginkan diadakannya emodul untuk membantu proses pembelajaran siswa agar siswa dapat lebih mengeksplore pengetahuannya dengan latihan soal. E-modul yang diharapkan siswa tidak hanya berisikan materi dan latihan yang monoton. Tetapi berisikan animasi yang menarik agar pembelajaran terasa tidak membosankan.

\section{Tahap Desain}

Tahap ini dikenal juga dengan istilah membuat rancangan. Pada tahap ini mulai menyusun materi yang akan dibahas di dalam e-modul, pemilihan software yang sesuai, pemilihan format emodul, dan rancangan awal desain dari e - modul yang akan dibuat. Media yang digunakan dalam penelitian ini adalah $\mathrm{e}$ - modul berbasis open ended yang dapat diakses dengan menggunakan handpone maupun laptop. Jika diakses menggunakan handpone dapat menggunakan browser yang terdapat pada handpone dan jika diakses menggunakan laptop media yang tampil berupa softfile dengan format file exe dan dapat diakses tanpa menggunakan aplikasi lainnya. Produk E-modul yang akan dikembangkan ini berbasis open ended yaitu menurut Shimada dalam (Rahmawati ES \& Harta, 2014) menjelaskan bahwa model Open-Ended adalah model pembelajaran yang menyajikan suatu permasalahan yang memiliki metode atau penyelesaian yang benar lebih dari satu, bukan meminta peserta didik mengarah pada satu jawaban benar melainkan lebih berfokus pada cara peserta didik untuk sampai pada penyelesaian masalah. Kemudian menurut Mina (Sekolah \& Pertama, 2006) Open-ended memberikan keleluasaan kepada siswa untuk berpikir secara aktif dan kreatif dalam melakukan pemecahan masalah dan sangat menghargai keragaman berpikir yang mungkin timbul selama proses pemecahan masalahnya. Oleh karena itu pada tahap pemilihan materi untuk e-modul ini dipilih materi sistem persamaan linier dua variabel ada beberapa pertimbangan saat pemilihan materi salah satunya karena terdapat berbagai metode untuk menyelesaikan permasalahan yang ada pada materi ini seperti metode eliminasi, substitusi, grafik dan campuran. Selain itu model open ended ini muncul pada latihan soal yang terdapat dalam e-modul peneliti merancang latihan soal berupa soal terbuka sehingga peserta didik dapat menyelesaikan soal tersebut menggunakan banyak metode sesuai kemampuan peserta didik. Ini sejalan dengan tujuan model open ended yang telah dijabarkan sebelumnya. Adapun hasil tahapan perancangan desain awal e-modul sebagai berikut. 


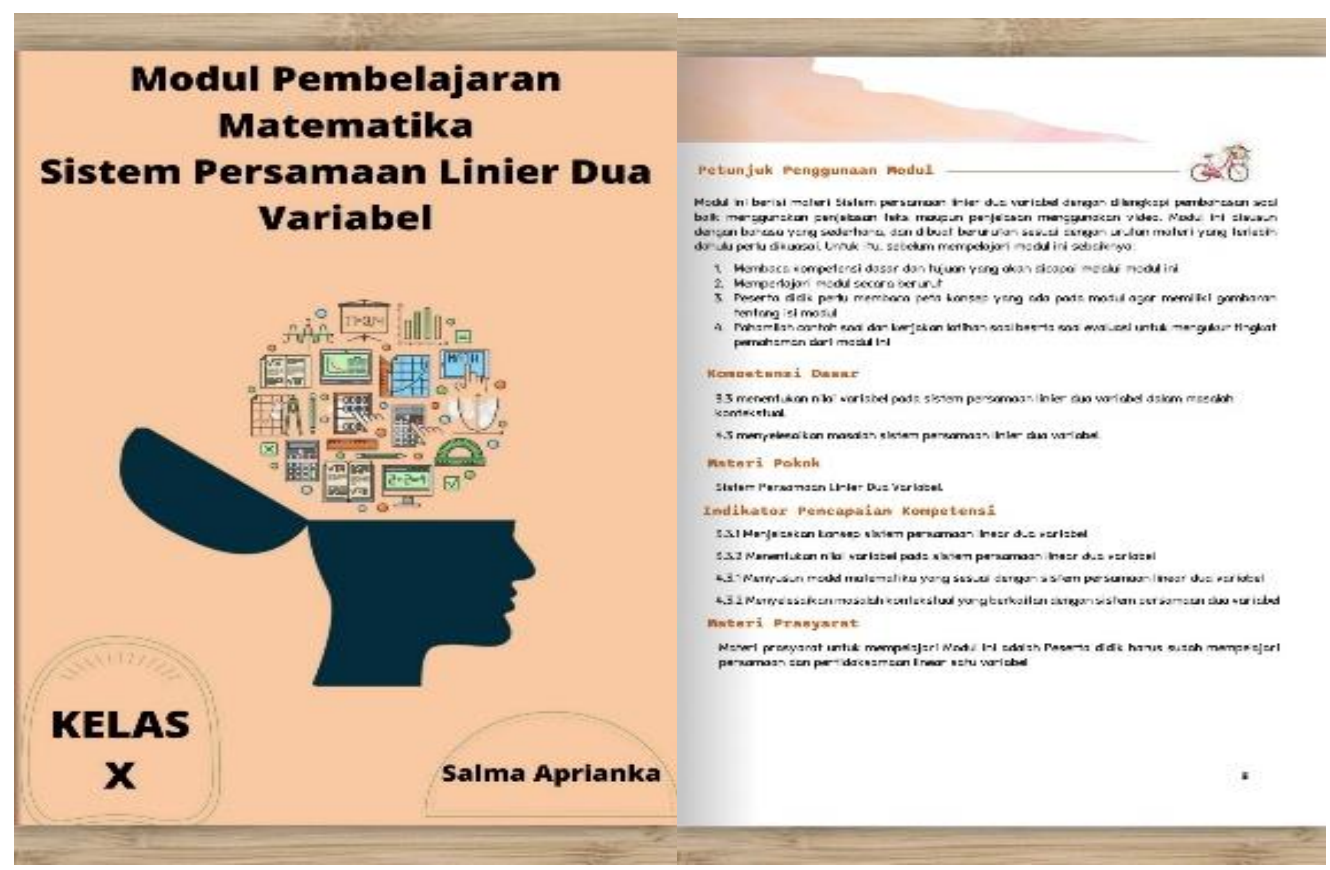

Gambar 1. Cover dan Pendahuluan

Gambar 1 merupakan gambar cover dan halaman pendahuluan dari e-modul berbasis open ended yang dikembangkan. Pada halaman pendahuluan berisikan petunjuk penggunaan modul, kompetensi dasar, materi pokok, indikator pencapaian kompetensi, materi prasyarat, manfaat e-modul, tujuan pembelajaran, dan peta konsep. Komponen pada halaman pendahuluan ini bertujuan untuk memberikan informasi secara singkat agar pembaca dapat mengetahui apa saja yang akan dipelajari serta mengetahui capaian belajar setelah mempelajari materi sistem persamaan linier dua variabel pada e-modul ini.

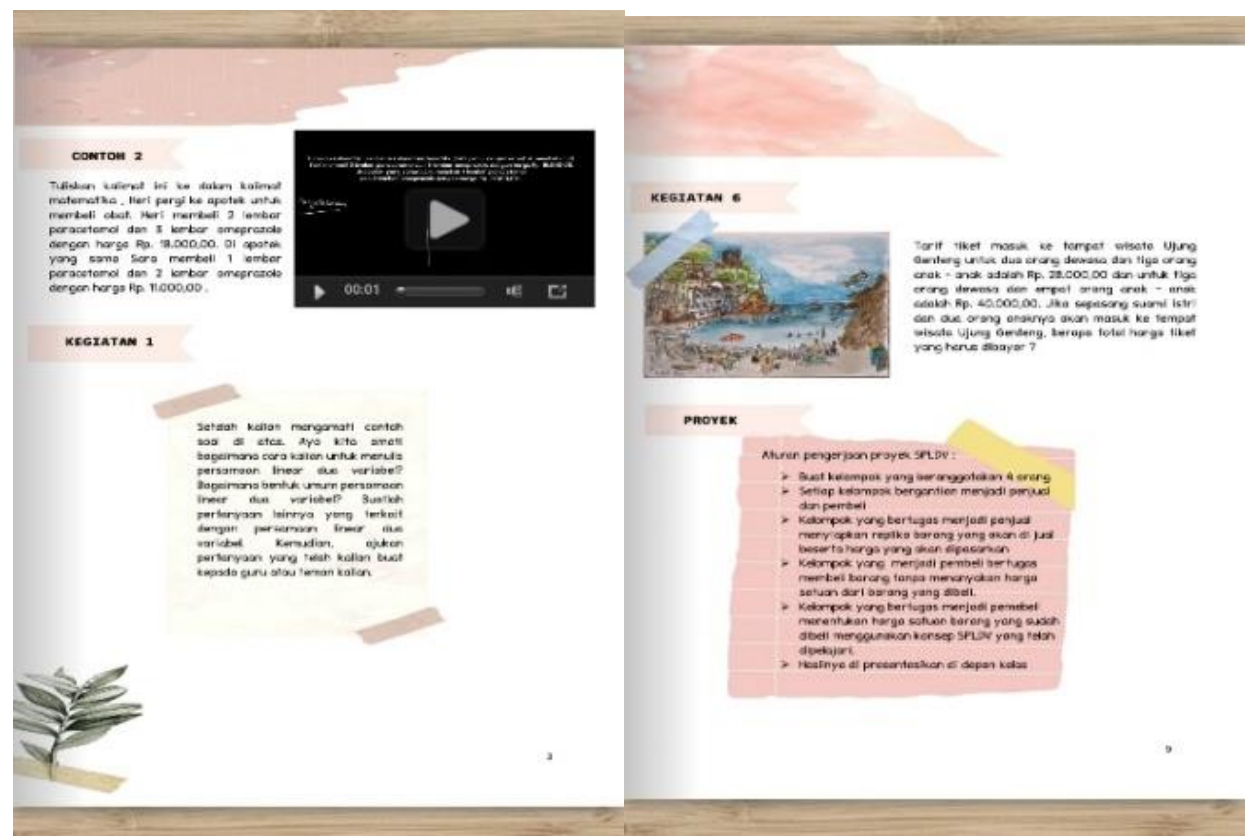

Gambar 2. Contoh soal dan proyek peserta didik 
Pada gambar 2 terdapat contoh soal yang dibahas menggunakan video agar pembaca lebih memahami materi pembelajaran yang ada dalam e - modul ini. $\mathrm{E}$ - modul ini juga dilengkapi dengan kegiatan siswa seperti soal latihan serta proyek yang bertujuan agar siswa dapat turut serta aktif dalam pembelajaran dengan cara praktik langsung.

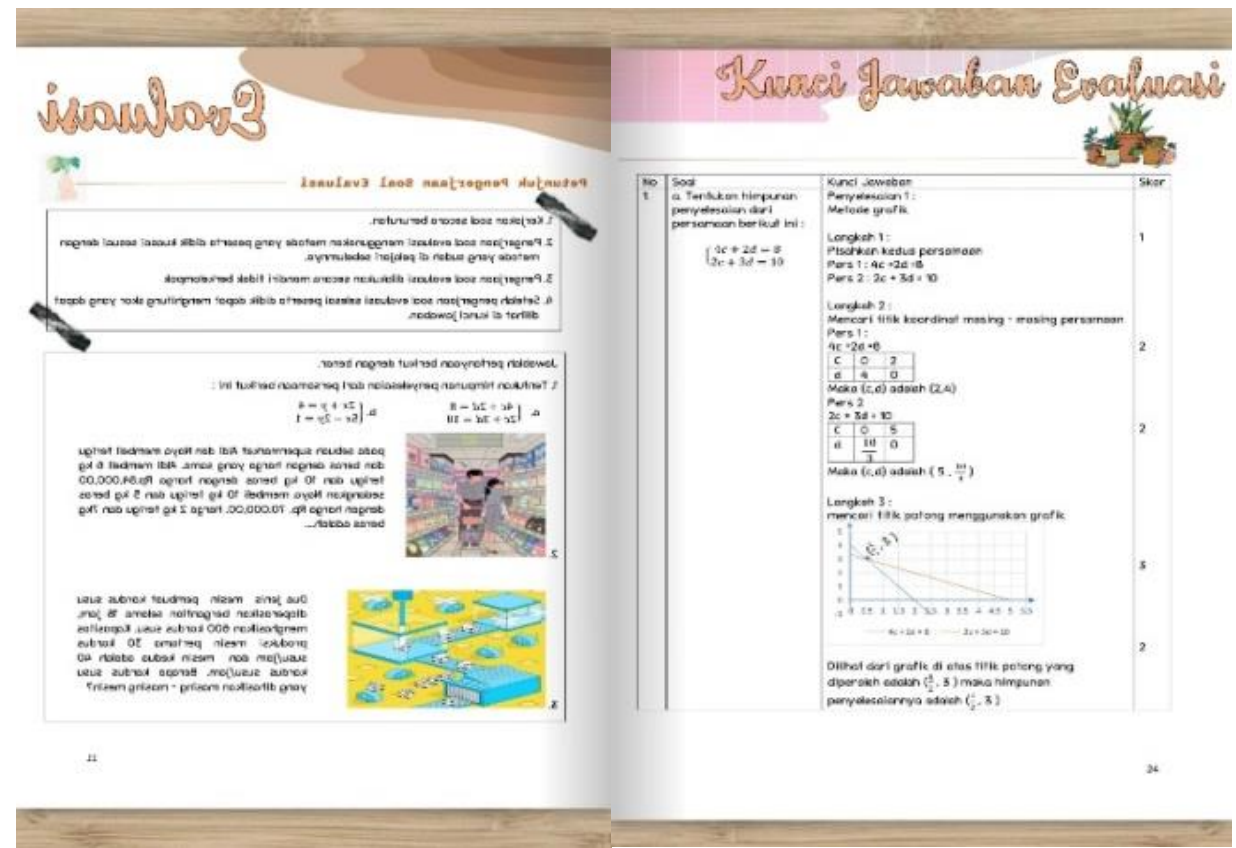

Gambar 3. Soal evaluasi dan Kunci jawaban

Pada gambar 3 terdapat soal evaluasi yang bertujuan untuk mengukur kemampuan dan pencapaian belajar pembaca. E - modul ini juga dilengkapi dengan kunci jawaban yang sudah ada pedoman penskoran agar siswa mengetahui kemampuan dalam menguasai materi sistem persamaan linier dua varibel. 


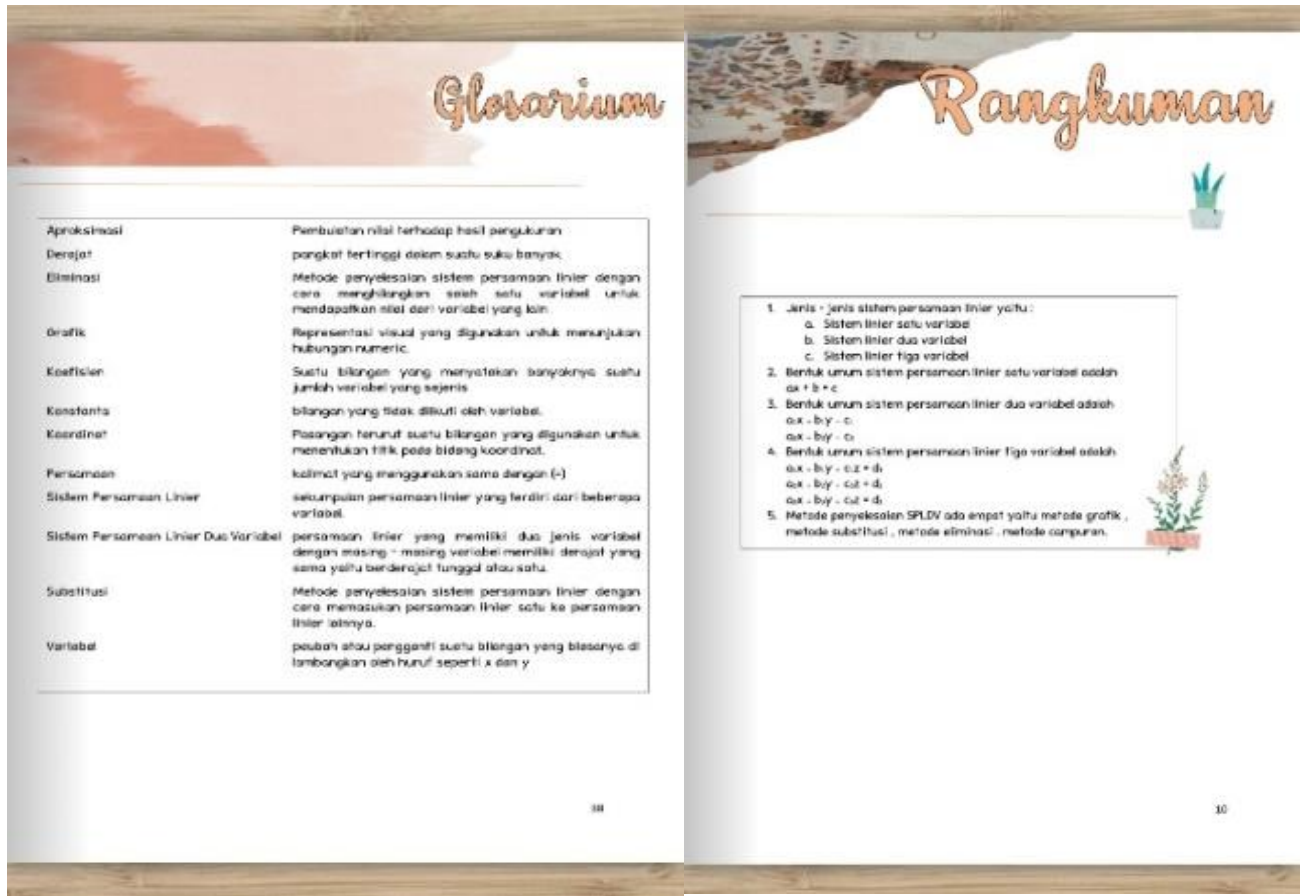

Gambar 4 Glosarium dan rangkuman

Pada gambar 4 terdapat glosarium yang dapat membantu pembaca untuk mengetahui istilahistilah asing yang terdapat pada e - modul ini. Rangkuman dibuat agar pembaca dapat mengetahui inti dari materi yang ada dalam e - modul ini.

\section{Tahap Pengembangan}

Pengembangan adalah proses mewujudkan desain tadi menjadi kenyataan, yaitu proses penulisan buku ajar dan juga proses pengembangannya berdasarkan kriteria-kriteria yang telah ditentukan (Hadi \& Agustina, 2016). Pada tahap ini dilakukan validasi materi oleh ahli materi dan validasi media oleh ahli media untuk menentukan baik atau tidaknya produk yang akan digunakan. Jika masih ada kekurangan maka dilakukan revisi hingga produk dinyatakan valid. Data hasil validasi ahli terdapat pada tabel 2 dan tabel 3

Tabel 2 Data Hasil Analisis Validasi Media

\begin{tabular}{|l|r|r|r|r|}
\hline \multirow{2}{*}{\multicolumn{1}{|c|}{ Aspek penilaian }} & \multicolumn{3}{c|}{ Validator } & \multirow{2}{*}{ Rata-rata } \\
\cline { 2 - 5 } & 1 & 2 & 3 & \\
\hline Ukuran Modul & 5 & 4,5 & 5 & 4,83333 \\
\hline Desain Sampul Modul (cover) & 4,6 & 4,3 & 4,6 & 4,47619 \\
\hline Desain isi modul & 4,3 & 4,9 & 4,2 & 4,48148 \\
\hline Hasil & \multicolumn{4}{c|}{$90 \%$} \\
\hline Kategori & \multicolumn{4}{c|}{ Sangat Layak } \\
\hline
\end{tabular}

Pada tabel 2 terdapat hasil analisis validisi media oleh tiga ahli. Aspek penilaian pertama yaitu penilaian ukuran modul yang mendapatkan nilai rata-rata yaitu 4,83. Aspek penilaian kedua yaitu penilaian desai sampul modul (cover) yang mendapatkan nilai rata-rata yaitu 4,47. Aspek penilaian ketiga yaitu penilaian desain isi modul yang mendapatkan nilai 4,48. Nilai keseluruhan yang diperoleh dari validasi media adalah $90 \%$ dengan kategori sangat layak. 
Tabel 3 Analisis Hasil Validasi Materi

\begin{tabular}{|c|c|c|c|c|}
\hline \multirow{2}{*}{ Aspek Penilaian } & \multicolumn{3}{|c|}{ Validator } & \multirow[b]{2}{*}{ Rata - Rata } \\
\hline & 1 & 2 & 3 & \\
\hline Kesesuaian Materi Dengan KD & 4 & 4,3 & 4 & 4,1111 \\
\hline Keakuratan Materi & 4,6 & 4,4 & 4 & 4,3333 \\
\hline Kemutahiran Materi & 4,5 & 4,5 & 4,5 & 4,5 \\
\hline Mendorong Keingintahuan & 4,5 & 4 & 4 & 4,1667 \\
\hline Teknik Penyajian & 4 & 5 & 4 & 4,3333 \\
\hline Pendukung Penyajian & 4,5 & 4,3 & 4 & 4,2778 \\
\hline Penyajian Pembelajaran & 4 & 3 & 4 & 3,6667 \\
\hline Koherensi Dan Keruntunan Alur & 5 & 4 & 4 & 4,3333 \\
\hline Lugas & 4,3 & 4 & 4 & 4,1111 \\
\hline Komunikatif & 5 & 4 & 4 & 4,3333 \\
\hline Dialogis Dan Interaktif & 4 & 3 & 4 & 3,6667 \\
\hline $\begin{array}{l}\text { Kesesuaian Dengan Perkembanagn } \\
\text { Peserta Didik }\end{array}$ & 4 & 4 & 4 & 4 \\
\hline Kesesuaian Dengan Kaidah Bahasa & 4 & 4 & 4 & 4 \\
\hline Hakikat Kontekstual & 5 & 4,5 & 4 & 4,5 \\
\hline Kemampuan Kontekstual & 4,1 & 3,9 & 4 & 4 \\
\hline \multicolumn{4}{|l|}{ Hasil } & $84 \%$ \\
\hline Status & & & & Sangat layak \\
\hline
\end{tabular}

Pada tabel 3 terdapat hasil analisis validasi materi oleh tiga validator. Aspek penilai pertama yaitu penilaian kesesuaian materi dengan KD yang mendapatkan nilai 4,11. Aspek yang kedua yaitu penilaian keakuratan materi yang mendapatkan nilai 4,33. Aspek ketiga yaitu penilaian kemutahiran materi yang mendapatkan nilai 4,5. Aspek keempat yaitu penilaian mendorong keingintahuan yang mendapatkan nilai 4,16. Aspek kelima yaitu teknik penyajian yang mendapatkan nilai 4,33. Aspek keenam yaitu penilaian pendukung penyajian yang mendapatkan nilai 4,27. Aspek ketujuh yaitu penilaian penyajian pembelajaran yang mendapatkan nilai 3,66. Aspek kedelapan yaitu penilaian koherensi dan keruntunan alur yang mendapatkan nilai 4,33. Aspek kesembilan yaitu penialain lugas yang mendapatkan nilai 4,11. Aspek kesepuluh yaitu penilaian komunikatif yang mendapatkan nilai 4,33. Aspek kesebelas yaitu penilaian dialogis dan interaktif yang mendapatkan nilai 3,66. Aspek keduabelas yaitu penilaian kesesuaian dengan perkembanagn peserta didik yang mendapatkan nilai 4 . Aspek ketigabelas yaitu penilaian kesesuaian dengan kaidah bahsa yang mendapatkan nilai 4. Aspek keempatbelas yaitu penilaian hakikat kontekstual yang mendapatkan nilai 4,5. Dan aspek kelimabelas yaitu penilaian kemampuan kontekstual yang mendapatkan nilai 4. Nilai yang diperoleh dari keseluruhan hasil validasi dari tiga validator materi yaitu $84 \%$ dengan kategori sangat layak. Pengembangan e -modul berbasis open ended ini berbantuan dengan beberapa software yaitu Canva, Pinterst, Picsart, flip pdf pro. Hasil akhir dari e - modul ini yaitu aplikasi berbentuk flipbook dengan format exe, dan flip book yang dapat di akses di browser.

\section{KESIMPULAN}

Berdasarkan hasil penelitian dan pengembangan, maka diperoleh kesimpulan sebagai berikut. Pertama E-Modul berbasis open ended Materi Sistem Persamaan Linear Dua Variabel pada 
pembelajaran daring untuk siswa SMK ini memiliki output berupa aplikasi berbentuk flipbook dengan format exe, dan flip book yang dapat di akses di browser. E - modul ini dapat digunakan pembaca dimana saja baik digunakan di sekolah maupun digunakan secara mandiri. Keunggulan dari e - modul ini yaitu terdapat materi yang mudah dimengerti, penjelasan soal menggunakan video serta terdapat gambar dan kunci jawaban yang dapat digunakan pembaca untuk mengukur kemampuan dalam mengusai materi yang ada dalam e - modul ini. Kedua e - modul ini mendapatkan nilai dengan kategori sangat layak, baik dari aspek materi yang memperoleh nilai dari ketiga validator ahli materi yaitu $84 \%$ maupun dari aspek media yang nilai dari ketiga validator ahli media yaitu 90\%. Maka E-Modul berbasis open ended Materi Sistem Persamaan Linear Dua Variabel pada pembelajaran daring untuk siswa SMK ini sangat layak untuk digunakan.

\section{UCAPAN TERIMKASIH}

Penulis mengucapkan terimakasih kepada pihak yang telah membantu penelitian ini baik validator yang telah meluangkan waktu, dan moril maupun SMK Hassina yang memberikan kesempatan untuk melakukan penelitian di sekola serta pihak lainnya yang membantu sehingga penelitian ini dapat selesai dengan baik.

\section{REFERENSI}

Cahyadi, R. A. H. (2019). Pengembangan Bahan Ajar Berbasis Addie Model. Halaqa: Islamic Education Journal, 3(1), 35-42. https://doi.org/10.21070/halaqa.v3i1.2124

Hadi, H., \& Agustina, S. (2016). Pengembangan Buku Ajar Geografi Desa-Kota Menggunakan Model Addie. Jurnal Educatio, 11(1), 90-105.

Haryati, S. (2012). Research and Development (R\&D) Sebagai Salah Satu Model Penelitian dalam Bidang Pendidikan. Research And Development (R\&D) Sebagai Salah Satu Model Penelitian Dalam Bidang Pendidikan, 37(1), 11-26.

Mendikbud. (2013). Peraturan menteri pendidikan dan kebudayaan Republik Indonesia Nomor 65 Tahun 2013 tentang standar proses pendidikan dasar Dan menengah. 2011, 1-13.

Muqdamien, B., Umayah, U., Juhri, J., \& Raraswaty, D. P. (2021). Tahap Definisi Dalam Four-D Model Pada Penelitian Research \& Development (R\&D) Alat Peraga Edukasi Ular Tangga Untuk Meningkatkan Pengetahuan Sains Dan Matematika Anak Usia 5-6 Tahun. Intersections, 6(1), 2333. https://doi.org/10.47200/intersections.v6i1.589

Nugroho, A. A., Putra, R. W. Y., Putra, F. G., \& Syazali, M. (2017). Pengembangan Blog Sebagai Media Pembelajaran Matematika. Al-Jabar: Jurnal Pendidikan Matematika, 8(2), 197. https://doi.org/10.24042/ajpm.v8i2.2028

Rahmadani, H., Roza, Y., \& Murni, A. (2018). Analisis Kebutuhan Bahan Ajar Matematika Berbasis Teknologi Informasi di SMA IT Albayyinah Pekanbaru. JURING (Journal for Research in Mathematics Learning), 1(1), 91. https://doi.org/10.24014/juring.v1i1.5230 
Rahmawati ES, Y., \& Harta, I. (2014). Keefektifan Pendekatan Open-Ended Dan Ctl Ditinjau Dari Hasil Belajar Kognitif Dan Afektif. Jurnal Riset Pendidikan Matematika, 1(1), 113. https://doi.org/10.21831/jrpm.v1i1.2669

Ramadhani, R., \& Fitri, Y. (2020). Pengembangan E-Modul Matematika Berbasis Model FlippedBlended Learning. Genta Mulia, 11(2), 150-163.

Ramadhani, R., Umam, R., Abdurrahman, A., \& Syazali, M. (2019). The effect of flipped-problem based learning model integrated with LMS-google classroom for senior high school students. Journal for the Education of Gifted Young Scientists, 7(2), 137-158. https://doi.org/10.17478/jegys.548350

Sekolah, D. I., \& Pertama, M. (2006). Pokok Bahasan Bilangan Pecahan.

Sudiarta, P., \& Putu, G. (2005). Doc1.pdf. Pengembangan Kompetensi Berpikir Divergen Dan Kritis Melalui Pemecahan Masalah Matematika Open-Ended., mei.

Suharsimi Arikunto, 1937-, \& Jabar, C. S. A. (n.d.). Evaluasi program pendidikan : Pedoman teoritis praktis bagi praktisi pendidikan / Suharsimi Arikunto, Cepi Safruddin Abdul Jabar. Jakarta: Bumi Aksara, 2004.

Sundayana, R. (2010). Doc2.pdf. Statistika Penelitian Pendidikan. garut: STKIP Garut Press

Wijayanto, \& Zuhri, M. S. (2014). Pengembangan E-Modul Berbasis Flip Book Maker Dengan Model Project Based Learning Untuk Mengembangkan Kemampuan Pemecahan Masalah Matematika. Prosiding Mathematics and Sciences Forum 2014, 625-628. http://prosiding.upgris.ac.id/index.php/masif2014/masif2014/paper/viewFile/487/436. 